\title{
Perancangan Software Aplikasi Berbasis Android untuk Menghitung Variabel Fisika Listrik dan Magnet
}

\author{
Selli Mariko, Andri \\ Universitas Indraprasta PGRI
}

Sellimariko85@gmail.com

\begin{abstract}
Sistem operasi pada sebuah smartphone sangat mempengaruhi kinerjanya. Android merupakan sistem operasi yang banyak digemari dan disematkan pada smartphone. Berbagai kelebihan serta fitur yang ditawarkan seperti: koneksi jaringan internet, multimedia dan keunggulan lainya membuat jumlah pengguna android sangat banyak. Banyak aplikasi yang dikembangkan untuk mendukung dunia pendidikan khususnya dalam bidang fisika.Mata pelajaran maupun mata kuliah fisika seringkali dianggap sulit oleh siswa sekolah dan mahasiswa tingkat awal. Tidak hanya siswa, tetapi juga masyarakat umum memiliki interpretasi yang sama terhadap mata pelajaran fisika. Hal ini dikarenakan fisika selalu berhubungan dengan rumus - rumus matematis kemudian diikuti dengan perhitungan yang sulit.Oleh karena itu peneliti menawarkan sebuah produk penelitian yang dapat menjadi solusi atas masalah tersebut yaitu software aplikasi berbasis android untuk menghitung variabel fisika listrik magnet.Permasalahan fisika pada kajian ini dibatasi pada materi yang berhubungan dengan listrik magnet.Sebagai bahan kelayakan, pada aplikasi yang dirancang untuk dapat digunakan oleh user/pengguna maka aplikasi tersebut sudah tervalidasi dan lolos uji coba kelayakannya.
\end{abstract}

Kata Kunci: aplikasi, android, listrik magnet

\section{Pendahuluan}

Palupi Annisa Auliani (2015:1) dalam harian berita elektornik mengemukakan hasil riset yang dilakukan oleh Google bersama TNS Australia. Hasil riset tersebut menyebutkan bahwa perilaku 1.000 pengguna smartphone, riset Google mendapati pemilik ponsel cerdas di Indonesia dikategorikan sebagai kelompok "social driven". Meskipun demikian, Indonesia masih punya catatan yang lebih baik untuk urusan belanja aplikasi berbayar.Dari delapan negara yang disurvei, Indonesia hanya kalah dari India soal kesukaan membeli aplikasi 
berbayar.Walaupun, Indonesia juga menjadi negara paling banyak mengunduh aplikasi gratisan.

Komunikasi dan informasi adalah hal yang sangat penting bagi dunia. Manusia sebagai mahkluk sosial sangat membutuhkan yang namanya komunikasi dalam rangka untuk menyampaikan informasi dari dan kepada orang lain. Komunnikasi yang terjadi secara langsung dapat berlangsung dengan mudah karena kedua atau lebih pihak bertatap muka secara langsung sehingga dapat menyampaikannya dengan leluasa. Namun apabila komunikasi tidak terjadi secara langsung akibat kedua atau lebih pihak tidak berada pada tempat dan waktu yang sama maka dibutuhkan sebuah alat atau media tertentu untuk berkomunikasi.

Pada saat ini terdapat berbagai jenis media yang dapat digunakan sebagai sarana komunikasi dan penyampai informasi elektronik seperti HP, internet, televisi, radio maupun cetak seperti koran dan majalah. Smartphone saat ini menjadi media yang paling banyak diminati oleh masyarakat karena berbagai kelebihannya dibandingkan media lainnya.Smartphone memiliki jenis sistem operasi yang sangat mempengaruhi kinerjanya.Sistem operasi yang paling digemari adalah android.Sistem operasi android memiliki perkembangan yang sangat cepat yang dapat dilihat dari berbagai versi android yang beredar dipasaran. Berbagai kelebihan baik dari fitur yang ditawarkan dalam hal koneksi internet, kelengkapan media, dan berbagai keunggulan lain yang dimiliki android membuat jumlah penggunanya di berbagai Negara terus meningkat setiap tahunnya, sehingga produksi android pun menjadi jumlah yang sangat fenomenal.

Perkembangan android yang cukup pesat belum mampu menjamah dunia pendidikan untuk meningkatkan kualitas pembelajaran.Sebagian besar penggunaan smartphone android lebih banyak digunakan untuk social media, game online dan belanja online.Di satu sisi masih banyak permasalahan yang berhubungan dengan pendidikan khususnya untuk mata pelajaran fisika.Kehadiran system operasi android belum berbagai permasalahan fisika secara signifikan.

G. B. Samudra, I.W. Suastra dan K. Suma, (2014) Mata pelajaran fisika seringkali dianggap sulit oleh siswa sekolah dan mahasiswa tingkat awal. Tidak hanya siswa, tetapi juga masyarakat umum memiliki interpretasi yang sama terhadap mata pelajaran fisika. Hasil wawancara awal dengan beberapa siswa menunjukkan bahwa fisika merupakan salah satu mata pelajaran yang sulit untuk dipelajari. Tidak hanya sulit dipelajari, fisika bahkan menjadi salah satu mata pelajaran yang dibenci oleh siswa

Berdasarkan pemasalahan-permasalahan di atas, perlu kiranya menerapkan metode mengajar yang mampu menumbuh kembangkan minat dan motivasi siswa untuk belajar fisika.Hingga saat ini, telah banyak tulisan mengenai upaya meningkatkan minat siswa terhadap pelajaran fisika.Hal ini dapat dilihat dari banyaknya makalah-makalah yang ditulis oleh para guru maupun peneliti di jurnal-jurnal pendidikan. Namun pada dasarnya, makalah makalah tersebut hanya akan menjadi kumpulan naskah tanpa makna jika tidak ada usaha untuk menerapkan metode pembelajaran yang inovatif dan berkelanjutan.

Sistem pembelajaran yang inovatif dan berkelanjutan dapat direalisasikan jika terdapat sinergi yang baik antar elemen dalam sistem pendidikan.Elemen-elemen ini terdiri dari guru dan kepala sekolah, murid, serta pemerintah. Guru dan murid sebagai elemen utama harus dapat saling bekerja sama untuk memenuhi tuntutan pendidikan yaitu penguasaan ilmu pengetahuan dalam hal ini pelajaran fisika, sedangkan kepala sekolah dan pemerintah sebagai fasilitator berkewajiban untuk memastikan kelancaran sistem pendidikan. 
Kesimpulan dari uraian tersebut di atas adalah bagaimana perkembangan system operasi android yang begitu pesat dapat menyelesaikan permasalahan - permasalahan materi fisika. Di sinilah peran dari peneliti untuk dapat mengembangakan berbagai aplikasi ataupun start up yang mampu menyelesaikan masalah tersebut. Peneliti mencoba menawarkan sebuah aplikasi perhitungan kasus - kasus fisika supaya dapat dilakukan perhitungan secara komputasi dengan system android.Dengan adanya aplikasi ini maka perhitungan fisika yang rumit dapat dilakukan secara cepat dan hasil perhitungan yang lebih akurat.

Edy Viktor Haryanto (2012:2) mendefinisikan secara umum sistem operasi adalah software lapisan pertama diletakkan memori computer, sedangkan software lainnya dijalankan setelah system operasi bekerja. System operasi akan melakukan layanan inti umum untuk semua software aplikasi tersebut. layanan inti umum tersebut seperti akses ke hard disk, management memori, scheduling task dan antar muka user. Hal ini menjadikan masingmasing software tidak perlu lagi melakukan tugas-tugas inti umum tersebut, karena dapat dilakukan oleh sistem operasi.

Biasanya penggunaannya hadir di ponsel pintar, PDA, tablet komputer, dan PMP. Dalam kasus, Sistem Operasi menyediakan suatu pustaka dari fungsi-fungsi standar, di mana aplikasi lain dapat memanggilfungsi-fungsi itu, sehingga dalam setiap pembuatan program baru, tidak perlu membuat fungsi-fungsi tersebut dari awal. Sistem Operasi secara umum terdiri dari beberapa bagian:

1. Mekanisme Boot, yaitu meletakkan kernel ke dalam memory.

2. Kernel, yaitu inti dari sebuah Sistem Operasi.

3. Command Interpreter atau shell, yang bertugas membaca input.

4. Pustaka yaitu fungsi standar yang dapat dipanggil oleh aplikasi lain.

5. Driver untuk berinteraksi dan control dengan hardware eksternal.

Muhammad K. Huda(2013) menjelaskan platform android yang merupakan produk asli Google yang paling populer danlaris di pasaran.Pembuatan aplikasi Android secara native (alami) membutuhkanpengetahuan pemrograman Java. Salah satu tools yang paling populer dan powerfull dalampembuatan aplikasi Android adalah Eclipse IDE yang dihubungkan dengan Compiler danEmulator Android SDK. Untuk membuat aplikasi Android, developer dapat menggunakansistem operasi Windows maupun Linux seperti Ubuntu maupun Mint. Paket Android SDKsupport juga untuk system operasi berbasis Linux. Kunci dari pembuatan aplikasi Androidsecara native adalah pengetahuan dasar Java Programming Language.

Sebelum melakukan koding pemrograman, seorang developer disarankan untuk membangunterlebih dahulu mock up atau desain awal aplikasi.Desainer maupun developer aplikasi android dapat menggunakan Droid Draw untuk membuat desain GUI (Graphical User Interface) dari software aplikasi yang akan dikembangkan.

Hugh D Young \&Roger AFreedman (2004) Muatan listrik, seperti massa adalah salah satu sifat dasarpartikel yang membentuk materi. Interaksi yang menentukan struktur dan sifat - sifat atomdan molekul terutama adalah interaksi listrik diantara partikel bermuatan listrik. CharlesAugustin de Coulomb (1736-1806) mengemukakan besarnya gaya listrik diantara duamuatan titik berbanding langsung dengan hasil kali muatan-muatan tersebut dan berbanding terbalik dengan kuadrat jarak antar muatan tersebut. Secara matematis dirumuskan:

$$
F=k \frac{Q_{1} \cdot Q_{2}}{r_{12}^{2}}
$$


Sedangkan medan listrik yang dihasilkan oleh sebuah muatan titik dapat dirumuskan:

$E=k \frac{Q}{r^{2}}$

Hugh D Young \&Roger AFreedman (2004) Sehingga energi potensial listrik merupakan kemampuan untuk melakukan kerja yang harus dikeluarkan oleh muatan karena pengaruh interaksidengan muatan yang lainnya.Interaksi ini dapat berupa tarika ataupun tolakan. Jadi dapatdisimpulkan bahwa energy potensial listrik adalah energy yang digunakan untuk melakukan gaya Coulomb.

$U_{e}=k \frac{Q_{1} \cdot Q_{2}}{r_{12}}$

Kondensator atau sering disebut sebagai kapasitor adalah suatu alat yang dapatmenyimpan energi di dalam medan listrik, dengan cara mengumpulkan ketidakseimbanganinternal dari muatan listrik. Kemampuan kapasitor dalam menampung sejumlah muatan dinamakan kapasitansi kapasitor yang memiliki satuan yang disebut Farad. Secaramatematis besarnya kapasitansi dirumuskan:

$C=\varepsilon_{0} \cdot \varepsilon_{r} \frac{A}{d}$

Karena muatan listrik akan menghasilkan medan listrik maka secara otomatis medan listrik merupakan suatu bentuk energy. Oleh karena itu energy yang tersimpan dalam kapasitor akan setara dengan:

$W_{C}=\frac{1}{2} Q^{2} \cdot C=\frac{1}{2} Q \cdot V$

Joko Budiyanto (2009) mendefinisikan medan magnetik sebagai ruangan di sekitar magnet yang masih terpengaruh gaya magnetik. Seperti pada gaya listrik, kita menganggap gaya magnetik tersebut dipindahkan oleh sesuatu, yaitu medan magnetik. Muatan yang bergerak menghasilkan medan magnetik dan medan ini selanjutnya, memberikan suatu gaya pada muatan bergerak lainnya Karena muatan bergerak menghasilkan arus listrik, interaksi magnetik dapat juga dianggap sebagai interaksi di antara dua arus. Kuat dan arah medan magnetik dapat juga dinyatakan oleh garis gaya magnetik. Jumlah garis gaya per satuan penampang melintang adalah ukuran kuat medan magnetik.

Besarnya medan magnet yang dihasilkan oleh aliran listrik tergantung pada jenis/ bentukmedia penghantarnya. Berikut beberapa persamaan untuk menghitung kuat medan magnetpada beberapa jenis kawat penghantar:

1. Kuat medan magnet pada kawat lurus

$$
B=\frac{\mu_{0} \cdot I}{2 \pi a}
$$


2. Kuat medan magnet pada kawat melingkar

$$
B=\frac{\mu_{0} \cdot I}{2 a}
$$

3. Kuat medan magnet pada pusat solenoid

$$
B=\frac{\mu_{0} \cdot I \cdot N}{l}
$$

4. Kuat medan magnet pada ujung solenoid

$$
B=\frac{\mu_{0} \cdot I \cdot N}{2 l}
$$

5. Kuat medan magnet pada toroida

$$
B=\frac{\mu_{0} \cdot \cdot \cdot N}{2 \pi a}
$$

Hendrick Antoon Lorentz seorang ahli fisika berkebangsaan belanda yang memperalajariinteraksi antara penghantar berarus listrik dalam medan magnet. Apabila terdapat sebuahkawat dengan panjang $l$ yang mengangkut arus $I$ yang berada di dalam medan magnet $B$.Ketika arus mengalir pada kawat, gaya diberikan pada kawat. Arah gaya selalu tegak lurusterhadap arah arus dan juga tegak lurus terhadap arah medan magnetic dan gaya inilahyang selanjutnya dikenal sebagai Gaya Lorentz. Besar gaya yang terjadi adalah:

1. berbanding lurus dengan arus $I$ pada kawat.

2 . berbanding lurus dengan panjang kawat $l$ pada medan magnetik.

3 . berbanding lurus dengan medan magnetik $B$.

4. berbanding lurus sudut $\theta$ antara arah arus dan meda magnetik.

Secara matematis Gaya Lorentz dapat dirumuskan:

1. Gaya Lorentz pada kawat berarus

$$
F_{L}=B \cdot I \cdot l \cdot \operatorname{Sin} \theta
$$

2. Gaya Lorentz pada muatan bergerak

$$
F_{L}=B \cdot q \cdot v \cdot \operatorname{Sin} \theta
$$

3. Gaya magnet oleh dua kawat sejajar

$$
F_{m}=\mu_{0} \frac{I_{1} \cdot I_{2}}{2 \pi d}
$$

Tujuan utama dari kegiatan Penelitian ini adalah:

1. Merumuskan dan mencari solusi persamaan matematis berbagai variabel yang berhubungan dengan listrik dan magnet.

2. Mengenal lebih dekat pemrograman yang secara spesifik dapat diakses melalui operating system yang berbasis android. 
3. Merancang sebuah aplikasi untuk menghasilkan produk penelitian berupa aplikasi untuk menghitung variabel fisika listrik dan magnet.

Adapun manfaat produk dari kegiatan penelitian ini adalah:

1. User/ pengguna mampu menghitung nilai variabel berhubungan dengan listrik dan magnet secara cepat serta hasil hitung yang lebih akurat.

2. Mengoptimalkan pemanfaatan perangkat teknologi informasi dalam hal ini adalah smartphone untuk mendukung dunia pendidikan.

3. Sebagai stimulus awal menghasilkan produk penelitian dalam bentuk aplikasi sejenis untuk menghitung variabel fisika lainnya.

4. Menghilangkan paradigma lama yang menganggap bahwa ilmu fisika adalah ilmu yang sulit untuk dipelajari.

5. Membuat masyarakat lebih senang dan mencintai ilmu pengetahuan, teknologi dan fisika.

\section{Metode Penelitian}

Jenis penelitian yang akan dilakukan oleh peneliti adalah R\&D (Research and Development). Seperti halnya jenis penelitian R\&D yang lainnya, maka penelitian ini akan menghasilkan sebuah produk berupa software (perangkat lunak) yang secara khusus digunakan untuk menghitung besaran fisika berkaitan dengan listrik dan magnet.

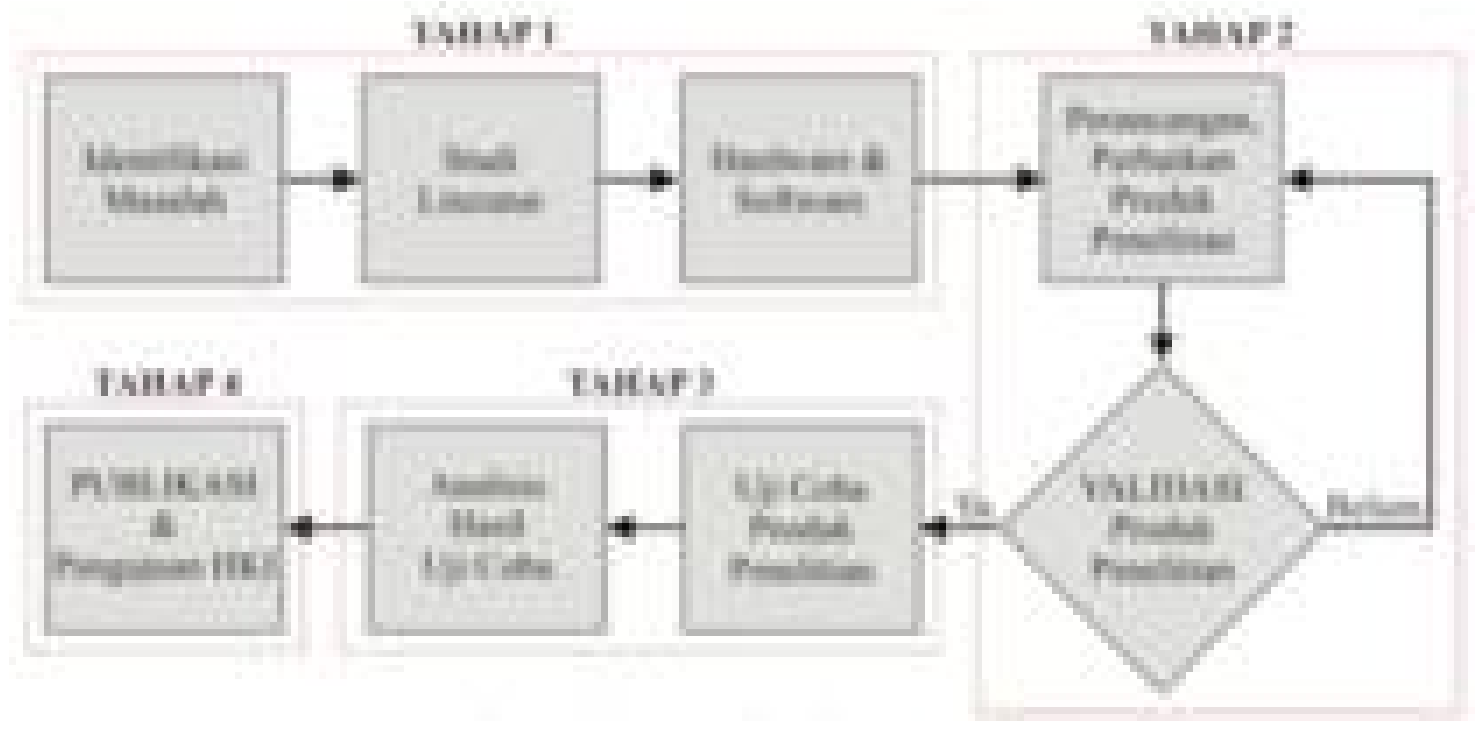

Gambar 1.Diagram Alir Tahapan Penelitian

Secara garis besar penelitian ini terbagi atas 4 tahap, yaitu: Tahap 1 (tahap persiapan), Tahap 2 (tahap pengembangan), Tahap 3 (tahap ujicoba) dan Tahap 4 (tahap pasca penelitian).

Tahap 1/ Tahap Persiapan, Pada tahap persiapan terdapat 3 kegiatan utama penelitian.Kegiatan pertama adalah identifikasi masalah.Peneliti menganalisis semua permasalahan yang dihadapi oleh pengguna smartphone terkait belum optimalnya penggunaan fitur yang tersedia untuk mendukung kegiatan perkuliahan.Kegiatan yang kedua adalah studi literature.Pada kegiatan ini menganalisis variabel-variabel yang muncul pada maeri listrik dan magnet. Selain itu pada kegiatan ini tim peneliti juga berusaha menemukan 
hubungan matematis antar variabel. Hubungan matematis antar variabel ini yang akan menjadi perintah jalannya program. Kegiatan ketiga adalah persiapan perangkat keras/ hadware sebagai tempat untuk menjalankan perangkat lunak dalam membuat software aplikasi.

Tahap 2/ Tahap Pengembangan, Tahap ini merupakan tahap inti dari kegiatan penelitian.Pada tahap ini ada dua kegiatan utama.Kegiatan pertama adalah perancangan, revisi dan pengembangan produk penelitian berupa software aplikasi untuk perhitungan fisika listrik dan magnet. Kegiatan kedua adalah proses validasi produk penelitian. Validasi penelitian mencakup validasi materi dan validasi media.Dari hasil validasi ini seorang validator dapat memberikan penilaian layak atau tidaknya software aplikasi ini untuk digunakan. Apabila produk lolos uji validasi maka akan lanjut ke tahap berikutnya, akan tetapi bila tidak lolos unji validai maka harus kembali direvisi supaya layak digunakan.

Tahap 3/ Tahap Uji Coba, Tahap ini merupakan tahap akhir dari kegiatan penelitian, diamana terdapat 2 kegiatan yang utama. Setelah produk penelitian lolos uji validasi, kegiatan selanjutnya adalah uji coba produk penelitian. Pada kegiatan ini uji coba akan dilakukan oleh mahasiswa dan dosen sebagai sasaran utama pengguna dari produk penelitian ini. Dari hasil uji coba tim peneliti akan menganalisis untuk mengambil kesimpulan tentang produk penelitian ini.

Tahap 4/ Tahap Pasca Penelitian, Setelah serangkaian proses pengembangan, validasi dan uji coba sudah berhasil maka selanjutnya peneliti akan melakukan publikasi ilmiah dalam skala lokal dan nasional. Tujuannya adalah supaya orang mengenal dan menggunakan software aplikasi yang dikembangkan untuk mendukung perkuliahan/ pembelajaran.Hasil produk penelitian ini adalah yang pertama, untuk produk sejenis belum ada yang mengembangkannya. Oleh karena itu, peneliti akan mendaftarkan produk penelitian untuk memperoleh HKI (Hak Kekayaan Intelektual).

Hasil/ produkpenelitian yang akan dicapai pada kegiatan penelitian ini adalah produk penelitian berupa softwareaplikasi yang berfungsi untuk menghitung variabel fisika listrik dan magnet berbasis android.Janner Simarmata (2010:29) mengemukakan bahwa software aplikasi atau perangkat lunak sudah mengubah berbagai aspek kehidupan yang dilakukan untuk meningkatkan produktivitas serta memberi kemudahan dalam pembelajaran dan konektivitas aspek kehidupan. Nilai dasar dari perangkat lunak itu sendiri beradapada kemampuan untuk memecahkan solusi terhadap permasalahan. Sebagian besar kode yang sering digunakan secara umum untuk kebanyakan aplikasi sudah dikembangkan sehingga tidak perlu menemukanny kembali.Komponen-komponenantar muka pengguna grafis (Graphical User Interface).Produk penelitian akan dijadikan dalam bentuk softfile dengan tipe .APK hal ini dilakukan supaya setiap user yang ingin menggunakannya dapat memasang pada smartphone.

Langkah pertama untuk menggunakan produk penelitian ini adalah install/ memasang aplikasi ke dalam smartphone. Caranya adalah dengan membuka file dengan tipe APK pada smartphone. Supaya smartphone dapat menginstall aplikasi tanpa dari PlayStore maka lakukan pengaturan dengan masuk ke SETTING >> LOCK SCREEN AND SECURITY >> UNKNOWN SOURCES (Allow Installation of App From Sources Other Then The Play Store). Setelah terpasang sempurna akan muncul icon aplikasi pada halaman menu.

Gambar 3 adalah tampilan halaman untuk menghitung variabel yang akan kita cari nilainya. Ada 4 bagian pokok dalam halaman ini, yaitu: 
a. Inputan, berisi variabel - variabel yang sudah diketahui nilainya. Kemudian nilai tersebut dimasukkan ke dalam menu yang dilingkari.

b. Tombol HITUNG, adalah tombol yang berfungsi untuk mengaktifkan proses perhitngan yang akan dilakukan.

c. Hasil Akhir, menunjukkan nilai dari hasil perhitungan varibel yang akan kita cari. Posisinya hasil akhir nilainya berada di atas tombol HITUNG.

d. Keypad, kepad berfungsi untuk memberikan nilai pada variabel inputan.

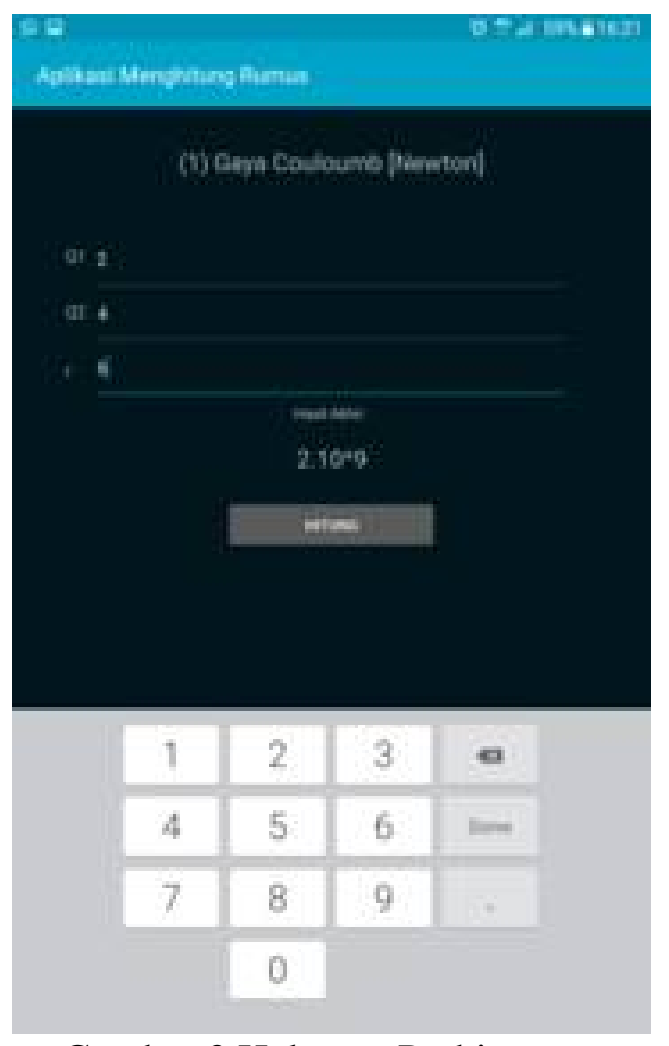

Gambar 3.Halaman Perhitungan

Untuk menjamin kualitas perangkat luank yang sudah dihasilkan perlu adanya sebuah pengujian untuk memastikan perangkat lunak mengimplementasikan pada suatu fungsi tertentu. Ade Djohar Maturidi (2012:65) Pengujian perangkat lunak merupakan elemen kritis dari jaminan kualitas perangkat lunak dan mempresentasikan spesifikasi, desain dan pengkodean. Ada 4 spesifikasi pengujian perangkat lunak yang meliputi:

1. Pengujian White Box.

2. Pengujian Black Box.

3. Pengujian Aplikasi dan Lingkungan Khusus.

4. Pengujian Berorientasi Objek.

Testabilitas perangkat lunak juga dilakukan untuk mengukur seberapa mudah perangkat lunak untuk diuji, karakteristik dari perangkat lunak yang diuji ini meliputi:

1. Operabilitias, semakin baik perangkat lunak bekerja semakin efisien dapat diuji.

2. Observabilitas, apa yang dilihat adalah apa yang diuji. 
3. Kontrolabilitas, semakin baik kita dapat mengontrol perangkat lunaksemakin banyak pengujian yang dapat dioptimalkan.

4. Dekomposabilitas, lebih cepat mengisolasi masalah dan melakukan pengujian kembali.

5. Kesederhanaan, semakin sedikit yang diuji semakin cepat pengujian.

6. Stabilitas, semakin sedikit perubahan semakin sedikit gangguan pengujian.

7. Kemampuan dipahami, semakin banyak informasi yang dimiliki semakin detail pengujiannya.

\section{Kesimpulan}

Mengacu pada tujuan, hasil dan pembahasan maka dapat disimpulkan, bahwa:

1. Sudah dirancang sebuah aplikasi yang berbasis android untuk menghitung variabel fisika yang berhubungan dengan listrik dan magnet.

2. Produk penelitian yang dihasilkan sudah melewati tahap validasi produk oleh ahli materi dan ahli media.

3. Produk penelitian secaraumum dapat berjalan dengan lanjar sesuai dengan spesifikasi smartphone yang terdapat di pasaran.

\section{Daftar Pustaka}

Budiyanto, Joko. (2009). Fisika : Untuk SMA/MA Kelas XII. Jakarta: CV Teguh Karya Haryanto, Edy Victor.(2012). Sistem Operasi Konsep dan Teori. Penerbit Andi: Yogyakarta Huda, Muhammad K. (2013). Peralatan Developer Aplikasi Mobile Untuk Semua Platform.http://mkhuda.com/teknologi/peralatan-developer-aplikasi-mobile-untuksemuaplatform/.Diakses: 5 Mei 2013

Maturidi, Ade Djohar. (2012). Metode Penelitian Teknik Informatika. Deepublish Publisher: Yogyakarta

Samudra, G. B., Suastra, I W., Suma, K. (2014). Permasalahan-Permasalahan yang Dihadapi Siswa SMA di Kota Singaraja dalam Mempelajari Fisika.E-Journal Program Pascasarjana Universitas Pendidikan Ganesha Program Studi IPA. Volume 4

Simarmata, Janner. (2010). Rekayasa Perangkat Lunak. Penerbit Andi:Yogyakarta

Young, Hugh D \& Freedman, Roger A. (2004).Fisika Universitas Edisi 10. Jakarta: Penerbit Erlangga 